Click www.researchjournal.co.in/online/subdetail.html to purchase.

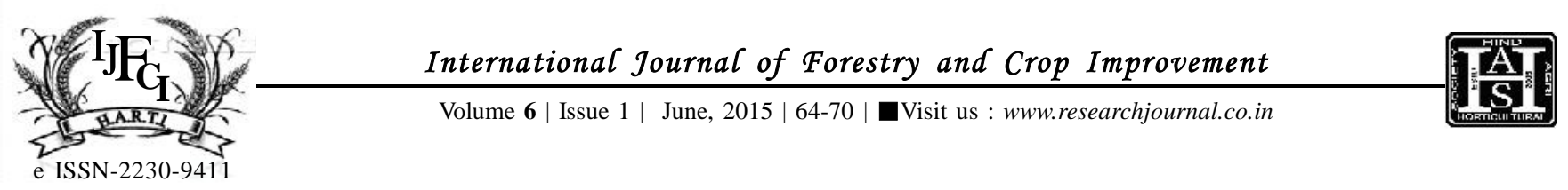

\title{
Growth, yield and nutrient contents and uptake by wheat as influnced by different residue management practices and nitrogen levels
}

\author{
K.A. SHAH, B.M. TANDEL AND G.J. BHIMANI
}

\begin{abstract}
An experiment was conducted for two consecutive years on same site at AAU, Anand, during the year 2004-05 and 2005-06, to evaluate the effect of crop residue management practices and nitrogen levels on yield and nutrient content and uptake by wheat. Eighteen treatment combination involving six residue management practices and three levels of nitrogen were tested in Factorial Randomized Block Design replicated thrice. Growth and yield attributes of wheat crop were increased due to different residue management treatments and FYM than that of control. Addition of wheat straw with $\mathrm{N}$ or $\mathrm{P}_{2} \mathrm{O}_{5}$ or both proved better than its application alone. However, addition of wheat straw @ $5 \mathrm{t} /$ ha along with $20 \mathrm{~kg} \mathrm{~N}$ and $20 \mathrm{~kg} \mathrm{P}_{2} \mathrm{O}_{5} /$ ha at 30 days before sowing was produced significantly the highest plant height at harvest, number of effective ear heads, length of era heads, test weight, grain and straw yields of wheat. Nitrogen, phosphorus and potash content and uptake by grain and straw of wheat were also found higher in same treatment. The application of $120 \mathrm{~kg} \mathrm{~N} / \mathrm{ha}$ was register significantly the highest all the growth and yield contributing character, including the grain and straw yields as well as net return of wheat. Similarly, nitrogen, phosphorus and potash content and uptake by grain and straw of wheat were recorded highest under the same treatment.
\end{abstract}

KEY WORDS : Wheat straw incorporation, Nitrogen, Nutrients content, Grain yield

How TO CITE THIS ARTICLE : Shah, K.A., Tandel, B.M. and Bhimani, G.J. (2015). Growth, yield and nutrient contents and uptake by wheat as influnced by different residue management practices and nitrogen levels. Internat. J. Forestry \& Crop Improv., 6 (1) : 64-70.

Article Chronical : Received : 21.03.2015; Revised : 27.04.2015; Accepted : 29.05.2015 